\title{
On Some Recent Exhibits
}

\author{
By Reginald A. Smith, F.S.A. \\ [Read 26th May I921]
}

Is April last the Society published two gold crescents found in Cornwall and now in Truro Museum; and in view of the proximity of Ireland, it is not surprising that others have been found; but the present exhibit (figs. I-3) is the most important of its kind, being the only case in which anything to indicate a precise date has been found with gold crescents anywhere. Mr. George Penrose, Local Secretary, and Curator of Truro Museum, sent with the three objects in question the following information :

'The two gold crescents (figs. I, 2) and bronze celt (fig. 3) sent for exhibition were found together, close to the edge of a low cliff at Harlyn or Perlaze Bay, near Padstow, Cornwall, sometime during the year I 864 .

' The property belonged to the late Mr. Hellyar, who lived at Harlyn House, and his workman who found the objects was excavating, in order to make a pond, at a point near the boathouse now standing east of the building known as Fish Cellars. Unfortunately full details of the discovery were not properly noted at the time, but there is sufficient evidence to indicate that a barrow had existed on the site.

'The objects appear to have been found at a depth of about $6 \mathrm{ft}$. from the surface. The labourer attached very little importance to the crescents, thinking they were only of brass, and on leaving work placed them around his legs and returned with them to his master's house.

'It was stated at the time that some other objects came to light but were thrown over the cliff by the labourer as being worthless. One piece he described as "like a bit of a buckle". The crescents were not regarded as of any special value, being black with tarnish and dirt, and were given to the children as playthings. Afterwards they began to show brightness at the edges, and Mr. Hellyar took them to a person who informed him they were of gold. He then showed them to the late Mr. C. G. Prideaux Brune, of Prideaux Place, Padstow, who communicated with the Duchy of Cornwall, when they were claimed on behalf of the Duke of Cornwall (the 
late King Edward VII) as treasure trove. Eventually the Duke of Cornwall directed that the objects should be deposited in the Museum of the Royal Institution of Cornwall, at Truro, at the same time paying Mr. Hellyar the value of the gold. To this sum was added a further amount raised by subscription.

' The association of the bronze celt with the two gold crescents

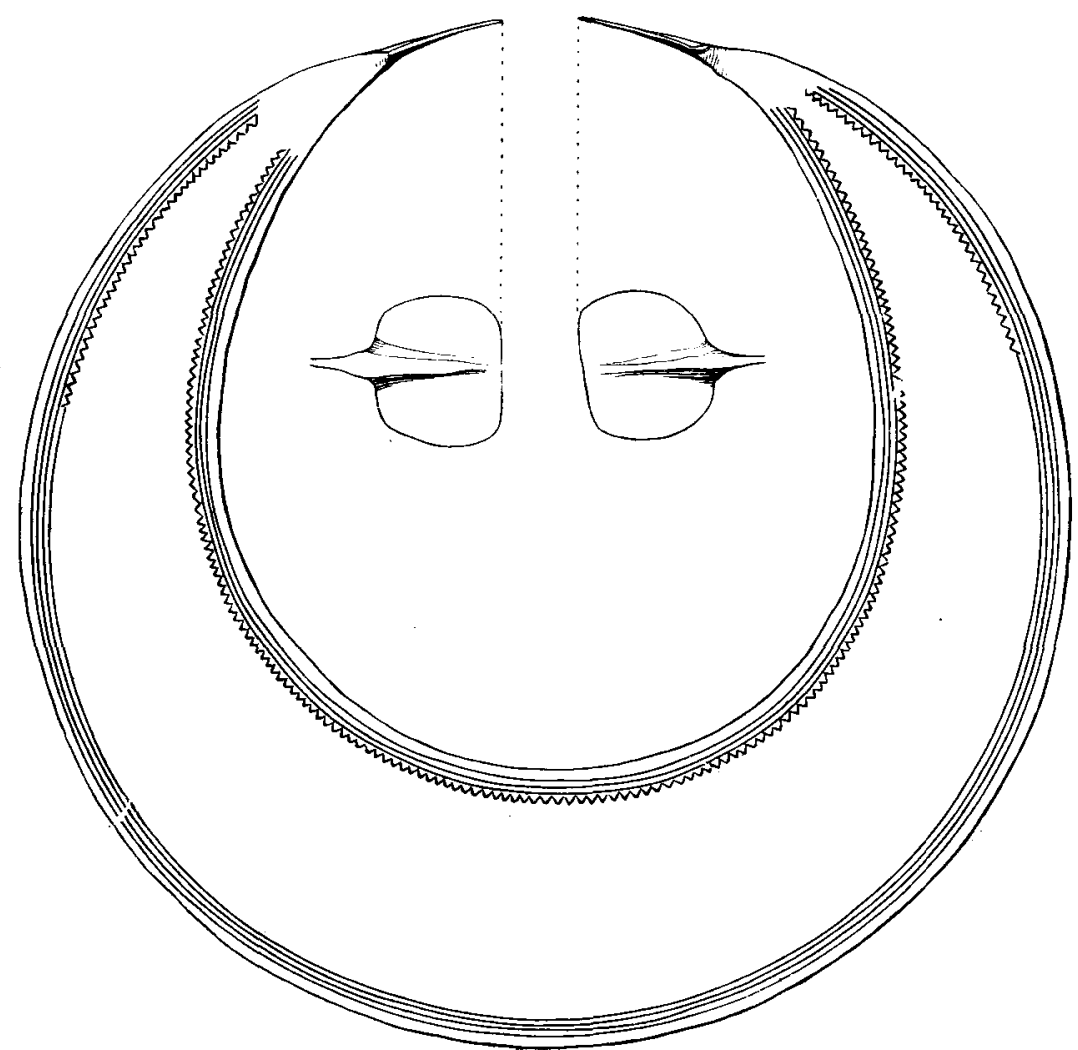

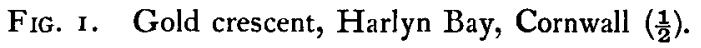

will be recognized as of great importance. In order to get corroboration of this I communicated recently with Mr. W.F. Hellyar, who well remembers the objects being found, and I have a letter which states that he is "quite sure the bronze celt was found with the gold crescents".

' On the cliffs adjoining are barrows, some of which have been opened and have produced cinerary urns, etc., which are undoubtedly of the Bronze Age.'

The find was noticed by Sir John Evans in Bronze Implements, 
p. 42 , but the dimensions of the celt are inaccurately given; and a fuller account with illustrations appeared in the Archaeological Journal, xxii, 277, where it is stated that ' the earth in contact with the objects was said to be of an artificial character, consisting of stones unlike the rest of the ground'. Further details were given by Mr. Crawford in the Antiquaries Journal, i, 294.

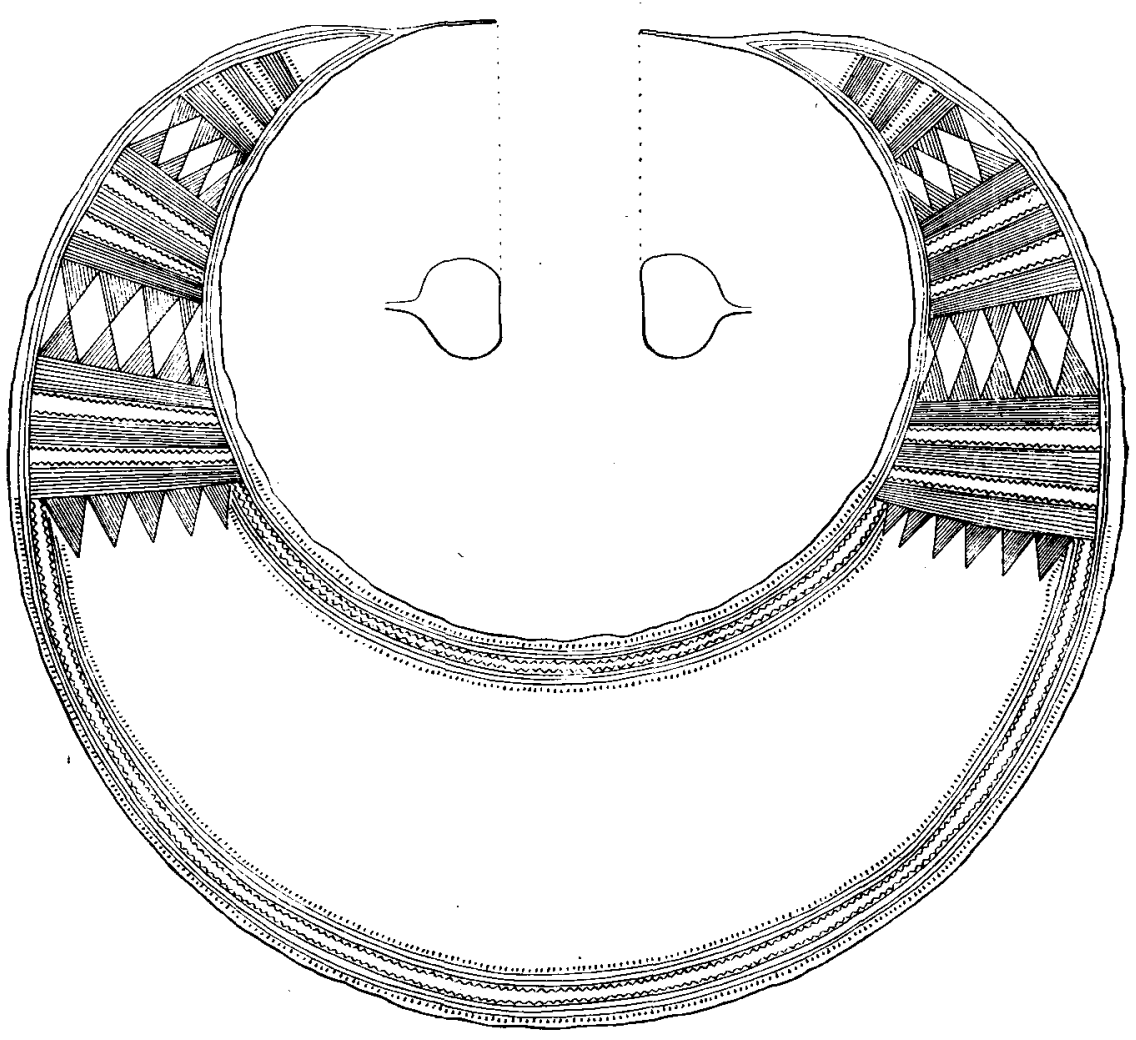

FIG. 2. Gold crescent, Harlyn Bay, Cornwall $\left(\frac{1}{2}\right)$.

The plainer crescent of the two (fig. I) is exceptionally thick and probably the heaviest known. It weighs $4 \mathrm{oz} .9 \mathrm{dwt}$. $\left(2 \mathrm{I}_{3}\right.$ grains $=138.7$ grammes), whereas the heaviest at Dublin is $4 \mathrm{oz}$. 4 dwt. 5 gr. (no. 8 in Mr. Armstrong's catalogue). The ornamentation consists of plain lines and small chevrons confined to the two edges of the front: the breadth is $8.25 \mathrm{in}$,, the opening $5 . I$ in. across, and the deepest part $2 \cdot 2$ in. Top views of the square terminal plates at right angles to the plane of the crescent are drawn within. 
The other crescent (fig. 2) is more richly and normally engraved; with chevrons and lozenges on a hatched ground. The diameter is $8.8 \mathrm{in}$., the opening $5.5 \mathrm{in}$. across, and the maximum depth 3 in. The weight (before a little gold was added in repair) was 996 grains $=64.59$ grammes; and a table of the four crescents found in Cornwall brings out a point of some significance. The last is from Penzance and is now in the British Museum, the others are in Truro Museum.

\begin{tabular}{lccc} 
Locality & Graiss & \multicolumn{1}{c}{ Troy } & Grammes \\
St. Juliot & 968 & 2 oz. O dwt. 8 gr. & 62.7 \\
Harlyn I & 2120 & 4 oz. 8 dwt. 8 gr. & 137.7 \\
Harlyn II & 996 & 2 oz. 1 dwt. 12 gr. & 64.5 \\
Penzance & 1060 & 2 oz. 4 dwt. 4 gr. & 68.8
\end{tabular}

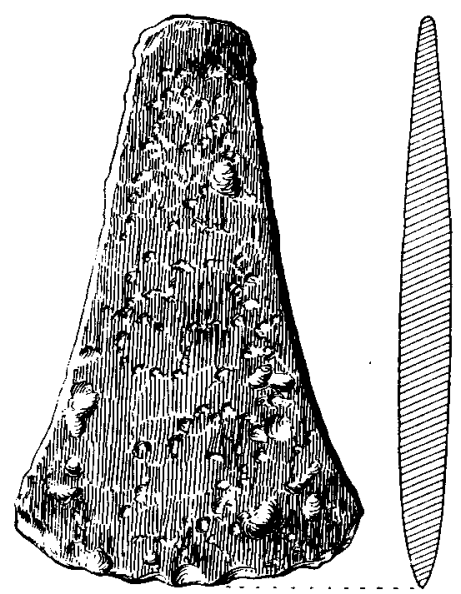

FIG. 3. Celt, found with gold crescents, Harlyn Bay ( $\left.\frac{1}{2}\right)$.

It will at once be seen that the heavier Harlyn specimen is exactly double the weight of that from Penzance; and in view of this relation it is permissible to suppose that the thin and damaged Harlyn crescent was originally 64 grains $=4 \cdot$ I grammes heavier, and equalled in weight that from Penzance, being half that of its fellow. To raise the St. Juliot specimen to that standard would require an addition of 92 grains (nearly 6 grammes), and it is rare indeed to find any connexion in weight among Irish gold crescents : hence the importance of the present case.

The flat celt (fig. 3) found with the Harlyn crescents has not been analysed, but is probably of copper, though the type is not quite the earliest in metal. It is 4.4 in. long, with a maximum breadth of 2.7 in. : the cutting-edge is expanded, perhaps by hammering 
to harden the metal; and the sides are roughly square but not flanged, nor is there any trace of a stop-ridge. It may thus be assigned to the first stage of the Bronze Age properly so-called, and the eighteenth century B. c. probably saw the manufacture of both celts and crescents on a large scale, perhaps a thousand years before the Kelts arrived in Britain. Whether the Druids were then in existence is another matter on which contradictory views are held by leading authorities; but an attempt has already been made to show that the gold crescents were cult objects, and the Druids of history may represent those who made and used them centuries before that mysterious name appeared in literature.

In the previous paper on the subject a connexion was suggested between the crescent as a sacred symbol and the horse-shoe still used as a lucky emblem. Sir. William Ramsay in the Journal of Roman Studies, viii, I 45, describes votive offerings in a temple to the god Mên near the Pisidian Antioch, dating from about the third century of our era; and illustrates the various forms of crescents in relation to horse-shoes. His own opinion is that Mên is not the moon-god (though it is the Greek term for month) but a male divinity associated with the moon-goddess. 'He.is rather the sun-god keeping company with the moon, so far as he represents any astronomical idea; but his nature is much wider. $\mathrm{He}$ is the great power of the divine nature as affecting the life of man in all ways, and his Anatolian name was Mannes.' This last is identified with the Hellenic supreme deity Zeus, the sun-god who runs his daily course through the heavens.

The name given to the crescent of Antioch is Tekmor, and it is represented on practically every dedication on the site. This crescent-shaped object is ordinarily taken as a symbol of the crescent moon (Mrs. Hasluck in Journ. Hellenic Studies, xxxiii, I I I), but there are various forms of it, and the types are classified as follows : (i) horned bull's head; (ii) horns with vanishing head; (iii) horns without head; (iv) crescent having no resemblance to horns ; but it is uncertain whether this bull's head preceded the crescent in order of development or vice versa. This point was also raised in the April number, and Spain mentioned as a possible intermediate link. A gold crescent, apparently of Irish type, was indeed found in a dolmen near Allariz, Galicia, and was published in 1875 by Ramon Barros Sivélo (quoted by Abbé Breuil in Revue Archéologique, xiii ( 192 I), p. 78).

Two complete specimens and parts of others in the British Museum have rendered familiar the type of shield used in the Early Iron Age, but the oval outline has not been hitherto 
represented. The model or toy (fig. 4) was exhibited by $\mathrm{Mr}$. W. J. Hemp, F.S.A., on behalf of Mrs. Oakden Ward, the grand-daughter of the late Henry Durden, most of whose collection was purchased for the nation in 1892 . The owner states that it was found at Hod Hill, near Blandford, Dorset, so that presumably it is contemporary with the abundant antiquities from that earthwork, which is 50 acres in extent (not 320 as stated in Arch. Journ. lvii, 53) and $470 \mathrm{ft}$. above the sea, containing in an angle a small Roman camp of 7 acres (not 70 acres) known as Lydsbury Rings. The date of occupation in force must have been
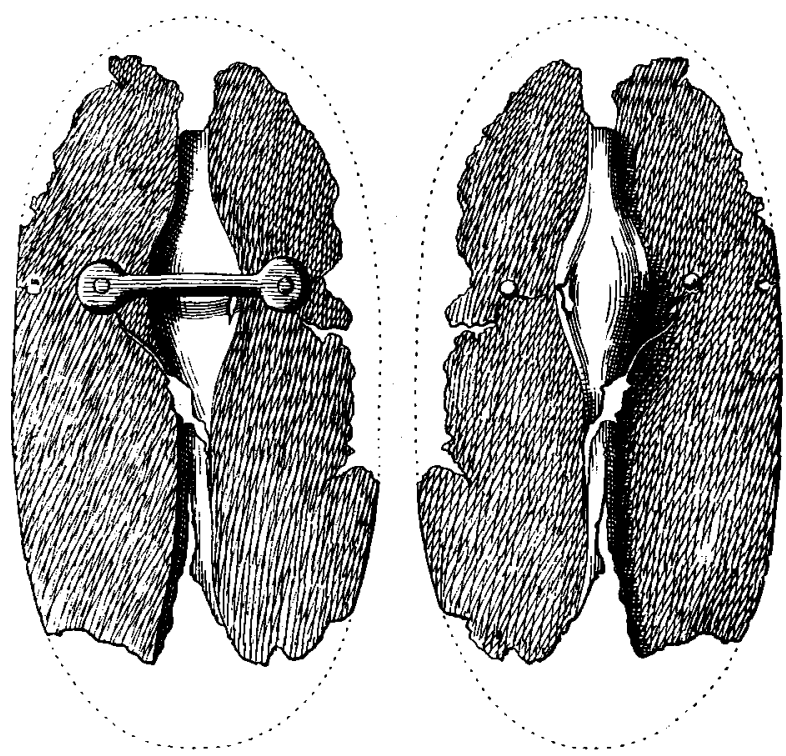

FIG. 4. Back and front of a model shield of bronze, Hod Hill, Dorset ( $\left(\frac{2}{3}\right)$.

A. D. $40-50$, and the fort was probably a centre of resistance to the Claudian invasion.

The bronze is damaged at both ends, but was about $4 \frac{1}{4}$ in. long and most probably of oval form. Across the back of the boss the grip is still in position; and the boss is spindle-shaped, tapering at both ends into a raised rib which no doubt reached both extremities of the shield. The contrast to the ordinary type is obvious, but the boss recalls that of the famous Witham shield, which is two or three centuries earlier than the Battersea specimen with its round boss and enamel decoration. This is against a local development of the type, and the model may have come over from Gaul a generation after the Battersea shield was made 
in this country. What few parallels there are point to such an origin.

Gaulish shields of the period of La Tène are fairly common : their evolution has been traced, but the oval form was not apparently reached till after the Roman conquest, and two illustrations in Déchelette's Manuel, part 3, figs. 496, 499, will serve to fix the date of the Hod Hill model. They show sculptures of Gallo-Roman origin with oval shields having round and spindle-

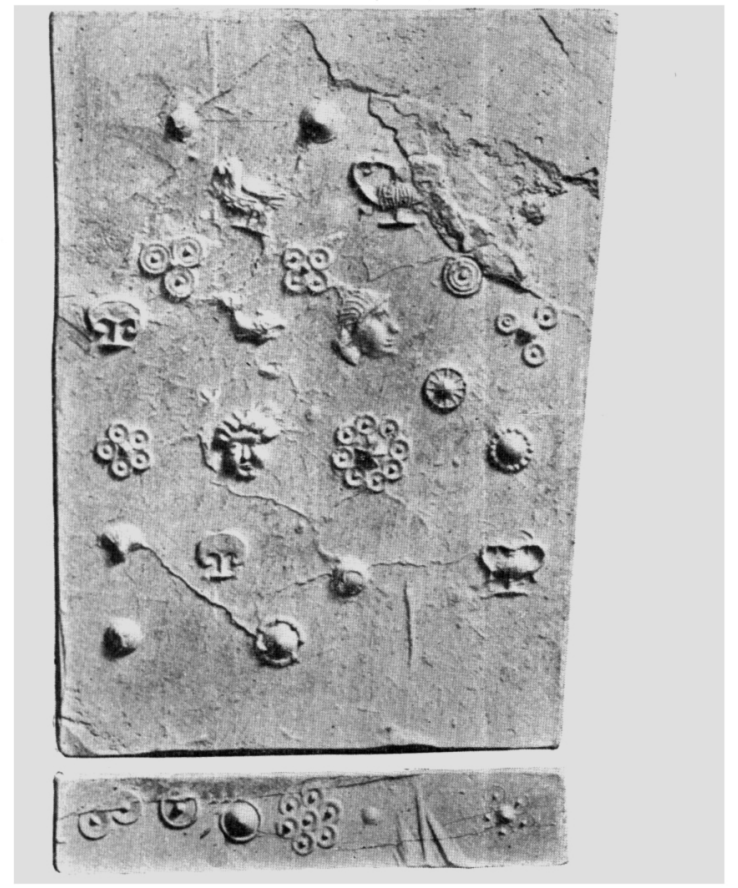

FIG. 5. Cast from shale mould for jewellery, Halton Chesters $\left(\frac{3}{4}\right)$.

shaped bosses, accompanied by a war-trumpet, amazon shields, helmets, and a boar-standard; and there is no need to go:further afield.

Medieval stone-moulds for ornamental metal-work are fairly common, but Mr. F. G. Simpson's exhibit is altogether exceptional, dating as it undoubtedly does from the Roman period in Britain. It is the property of Sir Hugh Blackett and was found by Mr. Simpson, during one of his periodical excavations on the Roman wall, on $24^{\text {th }}$ August 19 ro in the ditch of the vallum about 15 in. below the present surface in mixed and 
unstratified Roman material, at a distance of $\mathrm{I} 65 \mathrm{ft}$. east of the south-east angle of the fort of Hunnum (Halton Chesters). It consists of a slab of shale $4 \mathrm{in}$. long, $3.1 \mathrm{in}$. broad, and $0.7 \mathrm{in}$. thick, cut in intaglio on one face and at one end with no less than twenty-seven small designs, which are here illustrated from a plaster cast in relief (fig. 5). The nature of the stone and the absence of connecting channels are enough to prove that the mould was not intended for casting in metal; and the only explanation seems to be that gold-leaf was pressed into the patterns and filled with lead, pitch, sulphur or composition. These
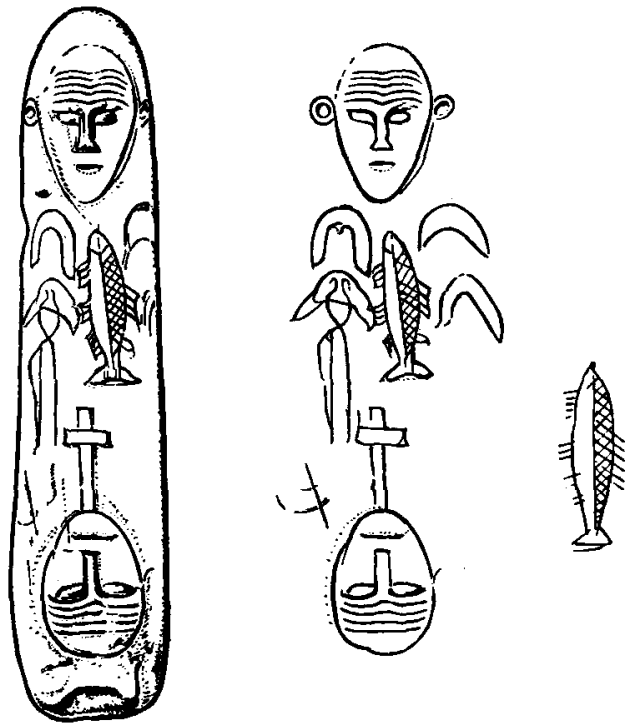

FIG. 6. Carved stone, with derelopment, Portsog $\left(\frac{1}{2}\right)$.

elements could be joined together and arranged to form elaborate jewels; and there is in the British Museum (Catalogue of Jewellery, Greek and Roman Dept., no. 3 IO4) a group of small gold discs, still separate, that might have come from a similar mould. There are $I 6$ moulds cut for cones or discs of ring-and-dot pattern; 2 vases of the Kantharos type; a bird and dolphin; 2 amazon shields; 2 human masks; a phallus; a crescent and pecten-shell.

Other Roman moulds were exhibited to the Society in 1908 (Proc. Soc. Ant., xxii, 38), but were for casting the various parts of bronze paterae or mirrors, not for shaping gold-leaf. They were of white Lias stone and were found on Lansdown, near Bath.

A relic of the Viking Period, but produced on Scottish soil, 
may be described as a trial-piece in hard black stone, in the form of an irregular cylinder 5.6 in. long. The illustration (fig. 6) shows a front view and all the engravings developed on the right. The owner, Capt. G. P. Crowden, says that it was probably found at Portsoy, Banffshire, by his father, Mr. J. T. Crowden, M.D., and everything points to a Scottish origin. There is indeed a parallel from the Broch of Burrian, N. Ronaldshay, Orkney, engraved with five- and six-pointed stars and a crescent, which suggests a finished work rather than a trial-piece ; and there is another of bone from the same Broch with a mirrorcase, crescent, and $V$ symbol. ${ }^{\mathrm{V}}$ Whatever their exact purpose, it is evident that the symbols belong to a class abundantly reprerented on the sculptured grave-stones of Scotland; and a few

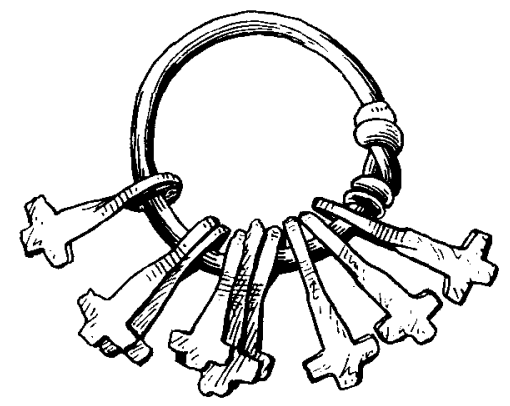

FIG. 7. Thor's hammers on ring, N. Bergenhus, Norway.

references to Messrs. Allen and Anderson's monumental work will suffice.

The two human faces with furrowed brows and the pair of rings are peculiar; and though there is a difference in date of two or three centuries reference may be made to one of the triangular metal mounts on a drinking-horn in the famous Taplow barrow ( $V . C, H$. Bucks., i, fig. 4 on coloured plate), which has a mask with wrinkles and a curl of hair on either side of the head, suggesting that the rings on the present carving represent hair and not ears. The cruciform adjunct to the chin of one, which might be regarded as the Christian emblem, is more likely a pendant in the form of Thor's hammer, of which a bunch is illustrated from Norway (fig. 7). There seem to be only seven cases of the plain cross on the Scottish monuments.

I J. R. Allen and Joseph Anderson, Early Christian Monuments of Scotland $(1903)$, p. 24 , figs. $23,22$. 
The crescents, plain or decorative, may be intended for the common symbol of the Scottish monu-
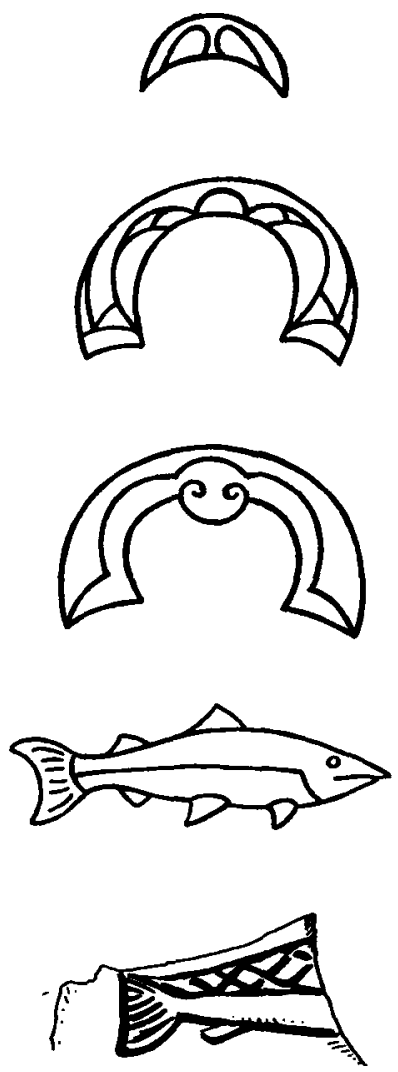

FIG. 8. Details from Scottish sculptures. ments, and two forms are illustrated (fig. 8).

The fish too is constantly represented on the standing crosses and may be derived from the Early Christian IXOYC, the letters of the Greek word for fish being the initials of a confession of faith. It is generally horizontal, occasionally sloping, but nearly all have the middle line (like a haddock); and in one case there is cross-hatching over one half, here reproduced from the damaged stone at Drumbuie, Inverness (A. and A., p. 99). For this the mackerel may have served as a model.

There are apparently both Christian and Pagan symbols on this trial-piece, which would be confusing were it not the case that the Scottish monuments exhibit what is obviously Christian inextricably mixed with forms that may belong to another faith. The matter has been fully discussed by Joseph Anderson (Scotland in Early Christian Times, 2nd ser., p. I 80 ), but remains a mystery; nor at present is there a chronological scheme to provide an exact date for our carving.

The remarkable bone carving exhibited by Mrs. Sturge, and since given to the British Museum, was formerly in the collection of Dr. Allen Sturge, M.V.O., who acquired it from a dealer with a label indicating an ethnographical origin (New Caledonia). It dates from the Viking Period and may be regarded as a trialpiece on which the carver sketched and practised designs then current in Britain and Scandinavia; but there is nothing to show where it was discovered. In the illustration (fig. 9) the bone is shown in perspective, with the entire design developed on the right. It forms an irregular cylinder 4.3 in. long, and the subjects are cut in low relief or merely engraved at random. Round the middle is a rough arcade of three bays, though 
nothing architectural was intended; and the three uprights that look like manikins are really the 'union-knot' or decorative terminal to two ribbon-like bands as on the Winchester bronze (Proc. Soc. Ant., xxiii, 398) and many another example of the Ringerike style (English list, op. cit., xxvi, 7I). In the third magnificent volume on the ship-burial of Oseberg, our Hon. Fellow Dr. Shetelig illustrates a very similar design in the form of a frieze (fig. IO) dating about I050 from the Dynna stone (his fig. 334), and surmises an oriental connexion in this phase of northern art, which comes between the periods of Jellinge and

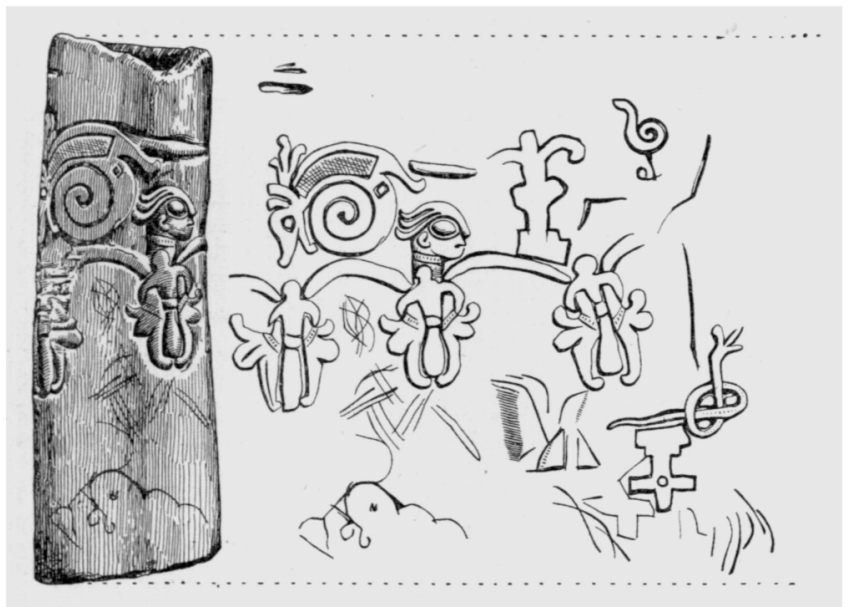

FIG. 9. Carved bone cylinder, locality unknown $\left(\frac{1}{2}\right)$.

Urnes, both these being based on the animal ornament of the Teutonic area.

The asp-like creature at the top resembles a jewel illustrated ix Rygh's Norske Oldsager, fig. 690; and the snake tied in a Stafford knot is commoner than the peculiar trefoil head which is seen also on a cross-shaft from Gilling West, Yorks. (V.C.H., ii, $1 \mathrm{I} 8$ ). The larger spirally coiled animal has a triple lappet much in the Ringerike style of Scandinavia, as at Somerford Keynes, Wilts. (Proc. Soc. Ant., xxvi, 67); but parallels are not plentiful for the coiled body or the human head in profile, which has some resemblance to the mounted figure on many of the gold bracteates (Allas for Nordisk Oldkyndighed,passim). The head is normally in profile, and the hair in this case is dressed in the Ringerike style.

The stepped cross is rather surprising and has a medieval look, but models in plenty were to hand in the gold coinage 
of the seventh century (e.g. V.C.H. Norfolk, i, 342); and publication is the royal roarl to a solution of such minor difficulties.

This trial-piece, apart from the style of the work, has several

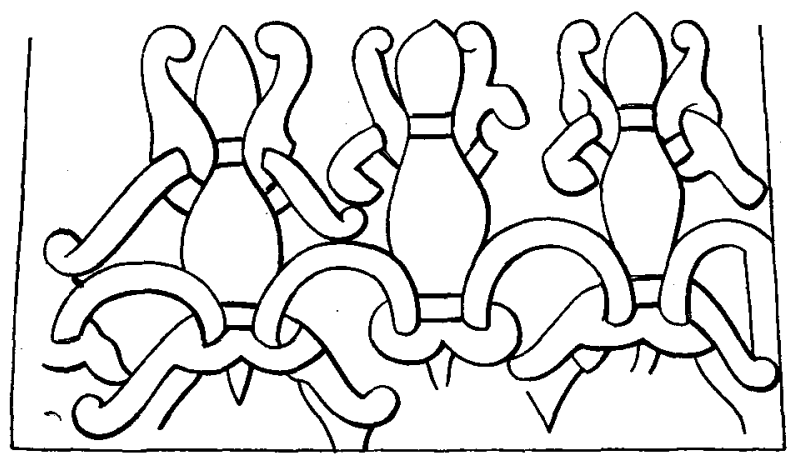

FIG. Io. Frieze from Dynna stone, Hadeland, Norway (Osetergfundet, iii, 3 I 8 ).

sufficiently close parallels in the British Isles, and may well have been cut on this side of the North Sea. Illustrations of others are given in Wilde's Dublin Catalogue, figs. 226-44; Munro, Lake-dwellings of Europe, pp. 352, 369; V.C. H. London, i, I62, 169; V.C.H. Yorks., ii, 106; and Jewitt's Reliquary, $\mathrm{v}, 7 \mathrm{I}$. 